\title{
Дмитро Архірейський
}

Дніпровський національний університет ім. Олеся Гончара

\section{Середземноморський вектор радянської зовнішньої торгівлі в 1920-х роках}

Мета статті - з'ясувати особливості радянської зовнішньої торгівлі в басейні Середземного моря у 1920х роках. Актуальність дослідження зумовлюється тим фактом, що середземноморська радянська зовнішня торгівля періоду нової економічної політики фактично ніколи не була окремою науково-історичною проблемою. Методи дослідження: хронологічний, історико-порівняльний, описовий. Основні результати: встановлено перелік країн Середземномор'я, з якими радянська держава підтримувала торговельні відносини протягом доби нової економічної політики; з'ясовано залежність радянської зовнішньої торгівлі від політичної кон'юнктури; проаналізовано українську складову радянської середземноморської торгівлі; на прикладі південного напряму радянської зовнішньої торгівлі показано, як Москва поступово обмежувала економічну самостійність Української Соціалістичної Радянської Республіки до повної іiї нівеляції. Практичне значення: результати дослідження можна рекомендувати для використання у синтетичних працях з історії України, СРСР, зовнішньої торгівлі та міжнародних відносин періоди 1920-х рр., розробки відповідних навчальних дисциплін та спецкурсів. Оригінальність: стаття є в цілому оригінальною, вона виконана з урахуванням напрацювань вітчизняних та зарубіжних дослідників, із залученням значного масиву документів низки українських $\mathrm{i}$ російських архівосховищ. Наукова новизна: вперше у вітчизняній історіографії охарактеризовано особливості радянської зовнішньої торгівлі 1920-х рр. у басейні Середземного моря, а також висвітлено роль у відповідних процесах УСРР. Тип статті: оглядова.

Ключові слова: зовнішня торгівля; РСФРР; СРСР; УСРР; Середземномор'я; економічні відносини

\section{Dmytro Arkhireyskyi \\ Oles Honchar Dnipro National University \\ Mediterranean vector Soviet foreign trade in the 1920 s}

The purpose of the article is to clarify the features of Soviet foreign trade in the Mediterranean basin in the 1920s. The relevance of the study is due to the fact that the Mediterranean Soviet foreign trade of the period of the new economic policy has never actually been a separate scientific and historical problem. Methods of research: chronological, historical-comparative, descriptive. The main results: established a list of Mediterranean countries with which the Soviet state maintained trade relations during the period of the new economic policy; clarified the commodity and raw materials nomenclature of export-import operations in the Mediterranean zone; it was established that one of the main reasons for the establishment by Western countries of trade relations with the Bolshevik state was the economic crisis of 1920-1921, which swept the West; At the end of the study period, the Soviet government used the Great Depression to exert economic pressure on Western countries; disclosed the dynamics of Soviet trade at that time in the southern direction; revealed the dependence of Soviet foreign trade on the political environment; analyzed the Ukrainian component of the Soviet Mediterranean trade of the 1920s, using the example of the southern direction of Soviet foreign trade, it is shown how Moscow gradually limited the economic independence of the Ukrainian SSR until its complete leveling. Practical significance: the results of the study can be recommended for use in synthetic works on the history of Ukraine, the USSR, foreign trade and international relations of the 1920s, the development of relevant academic disciplines and special courses. These materials can also be used to promote historical knowledge. Originality: the article is, in general, original, it was made taking into account the developments of domestic and foreign researchers, with the involvement of a significant array of documents from a number of Ukrainian and Russian archives. Scientific novelty: for the first time in domestic historiography the peculiarities of the Soviet foreign trade of the 1920s in the Mediterranean basin are characterized, and also the role in the corresponding processes of the Ukrainian SSR is. The scientific novelty of the work is also due to the introduction into scientific circulation of a significant complex of archival materials, primarily documents of various services and structures of the People's Commissariat for Foreign Trade of the RSFSR, the Ukrainian SSR and the USSR. Type of article: overview.

Keywords: : international trade; RSFSR; the USSR; Ukrainian SSR; the Mediterranean; economic relations 


\section{Вступ}

$\mathrm{Y}$

країна довгий час була позбавлена власної державності. Звісно, за останній час в царині піi відродження зроблено немало, але проблеми дорослішання даються взнаки. Україні важливо бути впізнаваною у світі, для чого важливою $\epsilon$ не лише їі зовнішня активність, але й елементарне знання світу в усьому його розмаїтті. Досить важливо вивчати й відповідний історичний досвід. Дослідження середземноморської радянської зовнішньої торгівлі 1920-х років як раз дає можливість опанувати такий досвід, адже Україна відігравала неабияку роль у цій торгівлі. Крім іншого, цей досвід доводить згубність цілковитої залежності країни та її населення від будь-яких закордонних «старших братів» та «союзних центрів».

Можна стверджувати, що середземноморська радянська зовнішня торгівля періоду нової економічної політики фактично ніколи не була окремою науково-історичною проблемою. Окремі ㄲï аспекти знаходили, звісно, відображення у нечисленних працях таких радянських, вітчизняних та зарубіжних дослідників, як Л. Марков (Марков, 1987), С. Кульчицький (Кульчицький, 1996), Л. Нєжинський (Нежинский, 2004), Ш. Мунчаєв і В. Устинов (Мунчаев и Устинов, 2002), Н. Верт (Верт, 2001), Ж. Соколофф (Соколофф, 2008), автор даної статті спільно 3 А. Новотоцьких (Архірейський, 2008; 2015; Архірейський та Новотоцьких, 2013). Фрагментарне дослідження даної теми, на наше переконання, є достатньою підставою звернути на неї увагу.

Мета дослідження - 3 'ясувати особливості радянської зовнішньої торгівлі в басейні Середземного моря у 1920-х роках.

Удослідженніактивновикористовувалися хронологічний, історико-порівняльний та описовий методи.

Залучення до дослідження зазначеної проблеми значного комплексу джерел, насамперед архівних, викликане, як зазначалося вище, iii недостатнім вивченням у попередній час. Отож, автором використовувалися документи різних структур Наркомату зовнішньої торгівлі РСФРР-СРСР та його філій в УСРР, що зберігаються в Центральних державних архівах вищих органів влади і управління України, громадських об'єднань України, Державних архівах Одеської та Харківської областей, Державному архіві Російської Федерації та Російському державному архіві економіки. Фрагментарно використовувалися матеріали «Собрания узаконений и распоряжений правительства за 1917-1918 гг.» (Собрание узаконений и распоряжений, 1942) та збірки документів «Москва-Рим: Политика и дипломатия Кремля, 1920-1939» (Москва-Рим, 2003).

\section{Результати дослідження.}

Основні принципи i характеристики радянської зовнішньої торгівлі 1920-х років, тобто періоду нової економічної політики, були сформовані ще за доби «воєнного комунізму». Насамперед це стосувалося принципу державної монополії зовнішньої торгівлі. Відповідно до декрету уряду РСФРР «Про націоналізацію зовнішньої торгівлі» від 22 квітня 1918 р. за цю монополію відповідав російський Наркомат торгівлі i промисловості (Собрание узаконений и распоряжений, 1942, ст. 432), у 1920 р. реорганізований у Наркомат зовнішньої торгівлі (далі - НКЗТ).

Економічна криза, очевидна по закінченню революції, явно загрожувала владі комуністів. Отож іiі подолання в контексті запровадженої в 1921 р. нової економічної політики мало стабілізувати соціально-політичну ситуацію в державі, заспокоїти населення, водночас підкріпивши більшовицький режим ресурсами і коштами. Лібералізуючи економіку, влада легалізувала приватний капітал, щоправда, надзвичайно обмеживши його законодавчо. Великі сподівання покладалися на зовнішню 
торгівлю, тому цю сферу необхідно було нормалізувати.

Консолідація внутрішніх економічних сил мала поліпшити становище радянської держави на міжнародній арені. Новий курс передбачав не просто активізацію радянського режиму на міжнародній арені, відносини із західними державами мали наповнитися передовсім якісним економічним змістом. Як зазначив російський дослідник Л. Нєжинський (2004), «обгрунтувавши необхідність добиватися встановлення 3 капіталістичними країнами мирних відносин, Ленін розгорнув широку аргументацію на користь якомога скорішого укладення договорів із Заходом (навіть ціною деяких поступок з боку Радянської Росії) i надання концесій закордонним підприємцям...» (с. 98). На порядку денному стояла й проблема укладання міждержавних торгових договорів та угод.

Хоча при переході до непу не було скасовано державну монополію зовнішньої торгівлі, влада, тим не менш, сподівалася, що активізація у цій сфері не тільки поповнить державну скарбницю, але й обумовить політичне визнання радянської влади 3 боку провідних капіталістичних країн. Таку політику більшовиків мотивувало й скасування у 1920 p. західними державами економічної блокади «країни Рад» (Верстюк, Дзюба и Репринцев, 1990, с. 224). Це зумовлювалося багатьма причинами: i військово-політичними перемогами більшовиків на просторах колишньої Російської імперії, і відсутністю консолідованого ставлення західних країн до більшовицького режиму, а головне, початком світової економічної кризи, пік якої припав на період з червня 1920 р. до квітня 1921 р. (Мунчаев и Устинов, 2002, с. 267).

Вважається, що економічна криза в Свропі почалася в країнах, які нещодавно отримали незалежність від Росії (Фінляндія, країни Балтії, Польща) (Верстюк, Дзюба и Репринцев, 1990, с. 229-231; Нежинский,
2004, с. 88, 89). Вони поспішили відмовитися від блокади більшовицької держави i встановити 3 нею дипломатичні відносини передовсім тому, що їхня економіка була пов'язана з російською ще з довоєнного часу. Найбільшими ж лобістами встановлення 3 більшовиками повноцінних економічних відносин 31920 р. стали англійські тредюніони та італійські соціалісти, які на батьківщині були парламентською партією (РДАЕ, спр. 5, арк. 74-81; ЦДАГО України, спр. 164, арк. 17; спр. 299, арк. 18). У своїх «Записках» головнокомандувач білої Російської армії П. Врангель згадував, як влітку 1920 р. його антантівські союзники, що виступали перед ним гарантами торгової блокади радянських чорноморських портів, потайки закуповували у більшовиків хліб, поставляючи їм натомість медикаменти (Врангель, 2002, с. 213, 214). Таким чином, Італія ще 31920 р. намагалася встановити економічні зв'язки 3 більшовиками, відкриваючи для них середземноморський напрям зовнішньої торгівлі.

1921 р. відзначився зовнішньополітичним i, як наслідок, зовнішньоторговельним проривом більшовицької держави. Починаючи 3 лютого, РСФРР офіційно уклала угоди, що мали й економічний зміст, iз Персією, Афганістаном, Монголією, а також торгові угоди з Норвегією, Австрією (Марков, 1987, с. 80; Нежинский, 2004, c. 91, 92). Радянські дипломати розпочали або продовжили серію переговорів 3 низкою країн (Англією, США, Німеччиною, Швецією, іншими) стосовно нормалізації двосторонніх торгових відносин. Англія 16 березня 1921 р. «ранішезаінші європейські держави уклала 3 Радянською Росією першу торгову угоду, що дала Радянському урядові визнання де-факто» (Майский, 1971, c. 141). Того ж дня було підписано політичний договір між РСФРР та кемалістською Туреччиною (Нежинский, 2004, с. 94).

Угода 3 Великобританією стала своєрідним імпульсом для підписання 
договорів 3 іншими державами, в тому числі на середземноморському напрямку. 3 березня 1921 р., зокрема, розпочалися переговори радянської держави 3 Італією, але тільки 26 грудня цього року Італією було підписано попередню мирну угоду з РСФРР та окремо з УСРР (Верстюк, Дзюба и Репринцев, 1990, c. 241; Нежинский, 2004, с. 101).

УСРР було підключено і до турецького напряму радянської зовнішньої політики. 35 листопада 1921 р. до 31 січня 1922 р. у Туреччині перебувала делегація УСРР на чолі з М. Фрунзе, яка 2 січня 1922 р. підписала договір про дружбу та братерство (Верстюк, Дзюба и Репринцев, 1990, c. 239, 241). Цей договір передбачав і активні економічні взаємовідносини. Уряд України вирішив відкрити кредит на суму 15 млн крб. «на попередні витрати 3 відправки надзвичайної місії в Ангору (Анкару. Авт.) для підписання мирного договору 3 Туреччиною» (156, арк. 86).

Протебільшовикинебулиббільшовиками, якби не мали на меті підпорядкування економічних взаємовідносин із Заходом політичній доцільності. Л. Каменєв, наприклад, у березні 1921 р. запевняв: «3 кожною лопатою вугілля, 3 кожною баржею нафти, яку ми отримаємо в Росії за допомогою західної технології, капітал буде рити собі могилу» (Соколофф, 2008, с. 322). На переконання французького дослідника Ж. Соколоффа (2008), більшовики щиро вірили, що «їм вдасться посіяти розкол в оточуючій їх зграї капіталістів, якщо вони спритно будуть підкидати кістки то одному, то іншому з них» (с. 322).

Отож всі зусилля радянської дипломатії в цей час були спрямовані на розкол капіталістичного світу, і зовнішня торгівля ставала ефективним інструментом такої політики. Економічна криза 1920-1921 pр., яку переживали держави Заходу, посилювала надію російських комуністів щодо швидких перспектив світової революції, епіцентром якоїімалистатипромисловорозвинутізахідні країни. Таким чином, зовнішня торгівля, як це уявляли більшовики Росії, мала слугувати знаряддям основної політичної мети розповсюдженню комуністичних впливів скрізь, де можливо. Імпортно-експортні операції, здійснювані протягом 1920-х pp. радянським НКЗТ, часто слугували прикриття агентурно-розвідувальної та підривної діяльності більшовицьких спецслужб. Державна монополія зовнішньої торгівлі, на думку політичного керівництва «країни Рад», дозволяла ефективно маніпулювати приватним бізнесом та урядовими структурами західних держав, зацікавлених у торгівлі з більшовиками.

Таким чином, вже у 1921 р. визначилися основні напрями радянської зовнішньої торгівлі. Найголовнішим із них був європейський, представлений передовсім економічно розвиненими капіталістичними країнами. Транспортне забезпечення цього напрямку здійснювалося як залізницею (через Польщу), так і морськими шляхами - переважно Балтійським i Чорним морями. Чорне море було важливим і для середземноморського напряму радянської торгівлі, другорядного з економічної точки зору, але важливого - 3 геополітичної. Російська імперія довгий час вела боротьбу за вихід до Середземномор'я. Звісно, й більшовики не могли ігнорувати цей напрям, який пов'язував їхню державу не тільки 3 Балканами та Південною Свропою, а й 3 Близьким Сходом та Північною Африкою. Крім того, напрям мав транзитне значення, адже виводив до таких глобально важливих транспортних артерій як Суецький канал та Гібралтарська протока.

Південний напрям був важливий для більшовиків і 3 політичної точки зору, адже значна частина Середземномор'я була представлена економічно слабкішими європейськими країнами (Італія, Іспанія, Греція), колоніальними володіннями європейських держав (Північна Африка), підмандатними територіями (Близький 
Схід) або ж країнами, де на той час точилася національно-визвольна боротьба (Туреччина). Перелічені території були цікавими для російських більшовиків 3 точки зору поширення тут комуністичної пропаганди та ідеології під прикриттям реалізації торговельних операцій.

Середземноморський напрям радянської зовнішньої торгівлі вартий уваги і тому, що важливу, якщо не ключову, роль на ньому відігравала Україна, яка об'єктивно посідала важливе місце в радянській економіці. На початок світової війни українські губернії мали достатньо розвинуту промисловість, мережу залізниць і портову інфраструктуру, сільське господарство, орієнтоване на європейський ринок, значні сировинні ресурси (вугілля, марганець, залізна руда тощо), якісний людський потенціал, нарешті, географічно Українатяжіла до Європи, маючи безпосередній вихід до центральної частини континенту, на Балкани i Свропейське Середземномор'я, в Малу Азію та Близький Схід. До війни Одеса вважалася головним пунктом «південноросійського експорту» (Великий князь Александр Михайлович, 2004, c. 303).

Нещадно воюючи 3 українськими національними режимами впродовж революції 1917-1921 рр., російські комуністи продемонстрували беззаперечне бажання необмежено розпоряджатися економічним потенціалом України. Недарма 28 грудня 1920 р. за ініціативи Москви було укладено угоду про воєнний та господарський союз між РСФРР та УСРР. Чинність договору поширювалася на певні промислові галузі України, які фактично переходили під прямий контроль Москви, а також на сферу зовнішньої торгівлі.

Втім, до часу створення Радянського Союзу УСРР мала деяку самостійність на зовнішній арені. Як зазначають українські дослідники Д. Вєдєнєєв та Д. Будков (2006), «велику активність Радянська Україна виявила у близькосхідному питанні й відносинах 3 Туреччиною» (с. 197), що підтверджувалося вище згаданою місією М. Фрунзе до Анкари. Певний час на початку 1920-х pp. у Стамбулі діяло українське торгове представництво (Вєдєнєєв та Будков, 2006, c. 197).

На думку Л. Нєжинського (2004), договори радянських республік з РСФРР, укладені в 1920-1921 рр., як вони самі вважали, давали їм державне право на певну самостійність у сфері зовнішньої політики та економіки (с. 147). Зокрема УСРР в 1921-1922 pp. уклала договори, крім вищеназваних країн, також з Латвією, Литвою, Німеччиною, Чехословаччиною. У цих країнах, а також в РСФРР i, за деякими даними, в Англії у березні 1922 р. діяли представництва УСРР (ЦДАВО України, спр. 75, арк. 4). На думку С. Кульчицького (1996), «дипломатичні зв'язки 3 іншими країнами були потрібні Раковському, щоб налагодити перш за все економічне співробітництво. Він створив наркомат зовнішньої торгівлі i [...] визнав ударність його роботи. 3 кінця 1921 р. утворено експортний фонд в 60 млн. крб. золотом. Натиснувши на центральні відомства, голова українського уряду домігся істотної самостійності в роботі НКЗТ. У сферу впливу наркомату увійшли Польща, Чехо-Словаччина, Румунія, балканські країни, Туреччина» (с. 296).

Як бачимо, діяльність НКЗТ УСРР у балканських країнах та Туреччині підтверджує, на перший погляд, тезу про важливість України для більшовиків на середземноморському напрямку. Проте, 3 іншого боку, представник уряду УСРР на ризьких переговорах з Польщею Е. Квірінг у записці «Про дипломатичні представництва УСРР» наголошував, що «республіка повинна у перспективі мати самостійні посольства у великих державах (Англія, Франція, США, Німеччина та Італія)», також мати посольство у Варшаві і консульства у Львові, Тернополі й Станіславі, представництва у Чехословаччині, Румунії, 
Австрії, тобто країнах 3 великою часткою українців. В інших країнах представники українського НКЗС мали бути радниками чи секретарями радянських представництв (Кульчицький, 1996, с. 294, 295). Така точка зору була негайно підтримана проводом УСРР, хоча очевидно, що при цьому республіка не ставала провідною саме на південному напрямку. Невизначений статус УСРР на середземноморських ринках, на наше переконання, пояснюється небажанням Москви дати Харкову надмірну економічну самостійність. Тим не менш, історичні джерела дозволяють з'ясувати справжню роль України у відповідних процесах.

Особливо відчутною була економічна присутність УСРР на Близькому Сході, включаючи Туреччину. Імпортуючи 3 Туреччини в цей час переважно специфічну сільськогосподарську продукцію, як правило цитрусові, радянська держава пропонувала на експорт певні види медикаментів (наприклад, сурум чи протичумну сироватку (ЦДАВО України, спр. 52, арк. 39 зв.)) та власної сільськогосподарської продукції. В 1923 р. турецькі пароплави допускалися до участі в торгових операціях з СРСР за умов отримання відповідних дозвільних віз радянського торгпредства в Туреччині (ДАОО, ф. Р-422, оп. 1, спр. 3, арк. 36).

21 листопада 1924 р. було створено Українсько-Східну торгову палату, яка мала забезпечувати економічні зв'язки з країнами Близького Сходу та Туреччиною (ЦДАГО України, спр. 1897, арк. 26). Втім, у контексті централізаторської політики Москви в сфері зовнішньої економіки в 1923-1924 рр. ця палата особливих перспектив не мала.

У цілому ж керівництво НКЗТ РСФРР ще до створення СРСР намагалося монополізувати всю радянську зовнішню торгівлю. Москва, наприклад, постійно цікавилася станом українських морських портів, їх здатністю приймати імпортні вантажі, станом припортових елеваторів, холодильників, іншої важливої інфраструктури (ДАХО, спр. 25, арк. 9). Через свої наркомати закордонних справ та зовнішньої торгівлі вона контролювала рух вантажних і пасажирських суден, які проходили через Одеський порт (ЦДАВО України, спр. 69, арк. 32-34). Український уряд був змушений постійно звірятися 3 московським центром, для кого саме - Росії чи України - надходять імпортні вантажі через українські порти (ЦДАГО України, спр. 1258, арк. 65) і т. п.

Певну роль в активізації радянських зовнішньоекономічних відносин, в т. ч. в зоні Середземномор'я, відіграв голод 19211923 pp. Реагуючи на нього, закордонні благодійні організації активно направляли для голодуючого населення України та Росії гуманітарні вантажі. Із США, наприклад, через Одеський, Маріупольський, Феодосійський порти ввозилися посівні кукурудза i пшениця. Посівна кукурудза закупалася і в Румунії, хоча $з$ цією країною через бессарабську проблему Україна не мала офіційних дипломатичних відносин (ЦДАГО України, спр. 1258, арк. 57 зв.). Судна 3 румунською кукурудзою йшли 3 Констанції на Одесу, Маріуполь та Миколаїв (ЦДАГО України, спр. 1258, арк. 24, 24 зв., 30, 30 зв., 39 зв., 48 зв., 54 зв., 64). Ближче до весни 1922 р. уряд УСРР прийняв рішення про закупівлю насіння в Болгарії (ЦДАГО України, спр. 1258, арк. 33 зв.). Через чорноморські протоки до радянських республік надходили вантажі по лінії АРА, місії Нансена тощо.

На відміну від Туреччини та Італії, Греція до 1924 р. не поспішала офіційно визнавати радянську державу, яка на початку 1920$\mathrm{x}$ років встановила фактично союзницькі відносини 3 кемалістською Туреччиною. Проте грецький торговельний бізнес не бажав втрачати можливості. Показовим є випадок 3 грецьким пароплавом «Лемнос», який 30 травня 1922 р. доставив 1250 т товарів комерсанта Понатопуло. 1100 т вантажу закупила Одеська контора Уповноваженого 
НКЗТ, яка, проте, відмовилась викупляти інші 150 т товарів через відсутність потреби в них. Деякі організації виявили бажання взяти ці товари дешевше. Отож, пропонувалося перевезти ці товари на склади внутрішньої Харківської митниці, сплачуючи ввізне мито частинами (ЦДАВО України, спр. 62, арк. 502). Грецькі судна в цей час часто обслуговували транспортні потреби радянської держави, яка до середини 1920-х pp. фактично не мала власного вантажного флоту.

Очевидним дипломатичним проривом для більшовиків була Рапалльська радянськонімецька угода 1922 р. Рапалло зумовило зближення «країни Рад» з Італією: 24 березня 1922 р. підписано радянсько-італійську торгову конвенцію, яка мала «розширити межі економічних відносин двох держав порівняно $з$ договором від 26 грудня 1921 р.» (Нежинский, 2004, с. 142, 143). Щоправда, радянський уряд відмовився ратифікувати цю конвенцію (мовляв, італійці отримали надто багато привілеїв), але тенденція красномовна.

Чим активнішим ставав середземноморський торговельний напрямок, тим швидше Москва обмежувала на ньому самостійність УСРР аж до повного скасування іiі в 1923 р. внаслідок створення СРСР. Україні, зокрема, було заборонено відкрити власне торгове представництво в тій же Італії. Коли італійці звернулися до НКЗС СРСР $з$ приводу невиконання раніше укладеного договору між компанією «Ллойд Трієстино» та Одеським губернським митним відділом, Москва виключила 3 переговорів українську сторону (ЦДАВО України, спр. 57, арк. 22).

Переживши на початку 1920-х pp. економічну кризу, західні країни почали солідаризуватися, що змушувало Москву активізувати свою зовнішню політику, роблячи ставку на двосторонні домовленості. У південному напрямку протягом 1924 р. були встановлені дипломатичні відносини 3 фашистською Італією (7 лютого) та Грецією (8 березня) (Верстюк, Дзюба и Репринцев, 1990 , с. 250, 251; Соколофф, 2008, с. 332). У 1924 та 1926 рр. СРСР уклав відповідно 3 Італією та Грецією й митні конвенції. Дипломатичні відносини між СРСР та Францією було встановлено 28 жовтня 1924 p. (Верстюк, Дзюба и Репринцев 1990, с. 254; Соколофф, 2008, с. 332). Це стало можливим після перемоги на травневих виборах у Франції лівих партій, однак протягом 19251927 pp. між країнами продовжувалися суперечки навколо царських боргів, які не дали результатів і ускладнили відносини. Також СРСР був незадоволений політичною допомогою, яку Франція надавала Польщі та Румунії (Верт, 2001, с. 236).

Середземноморський напрям враховувався радянським керівництвом i при розробці більш глобальних економічних проектів. Наприклад, НКЗТ СРСР, розробляючи проект пропуску транзитних вантажів радянською територією, один 3 таких маршрутів прокладав від західного державного кордону до чорноморських портів і далі - до Туреччини (ДАРФ, спр. 321 , арк. 5, 6).

На середину 1920-х рp. важливими торговими партнерами СРСР на Півдні були Італія, Франція, Туреччина. Крім того, Середземномор'я залишалося важливим торговельним шляхом до деяких країн Західної Свропи (Англії) та Америки. 3 логістичних міркувань країни Середземномор'я мали відчутну вагу для українського експорту. Так, у 1925/26 господарському році Англія ввезла 26,9 \% українського експорту, Німеччина - 18, Італія - 7,4, Франція - 6,8 \% (ЦДАГО України, спр. 2302 , арк. 14, 15). У наступному році список імпортерів України мав такий вигляд: Англія - 24,3 \%, Німеччина - 17,3, США - 13,3, Італія - 9,1, Туреччина -8 , Чехословаччина - 7,3, Польща - 6, Австрія - 5,7, Франція - 3,2 \% (ЦДАГО України, спр. 2302, арк. 15). Зауважимо, значна частка українського 
експорту вивозилася Чорним морем і далі, Середземним.

Українська зовнішня торгівля середини 1920-х pp., як і в попередній період, базувалася, головним чином, на експорті зерна. Український хліб в середині у цей час продавався до Італії, Франції, Англії, країн Балтії (ЦДАГО України, спр. 2302, арк. 22). Вагому частину українського експорту складала м'ясна продукція, що пояснювалося збільшенням поголів'я худоби та покращенням іiї якості на середину 1920-х pp. Українськими фахівцями місце республіки у загальнорадянському м'ясному експорті оцінювалося позитивно. Виходячи 3 того, що радянська м'ясна продукція вивозилася переважно в країни Середземномор'я (Італія, Франція, Греція, Туреччина, Сгипет, Мальта), вважалося, що «Україна має значні переваги щодо завоювання цих ринків, ніж інші райони СРСР» (ЦДАГО України, спр. 2302, арк. 29).

Намагання радянського керівництва використовувати міждержавні економічні відносини для досягнення політичних цілей не могло рано чи пізно не призвести до негативних наслідків. На думку Ж. Соколоффа (2008), «друга половина 1920-х років вказала Кремлю на те, що в нього немає справжніх міжнародних відносин... Більшовизм, який спочатку налякав буржуазію, потім став викликати у неї лють... Усе це загрожувало обернутися повним фіаско» (с. 418). У жовтні 1926 р. Москва ледь не розірвала дипломатичні відносини 3 Францією та Італією через підтримку ними претензій Румунії на Бессарабію.

Вакуум, утворений завдяки погіршанню економічних відносин з Францією та Італією, на південному напрямку радянської торгівлі в другій половині 1920-х рр. швидко заповнила Туреччина, яка під управлінням реформатора Ататюрка поступово стабілізувалася. В 19261927 рр. через Одеський порт імпортувалася турецька бавовна, завезенням якої займалося Акціонерне товариство «Текстильімпорт» (ДАОО, ф. Р-962, оп. 1, спр. 67, арк. 18).
Фактичний стан торговельних відносин між СРСР i Туреччиною було юридично закріплено лише 11 березня 1927 р. «Угодою про торгівлю і мореплавство». Між державами була укладена й Митна конвенція, котра гармонійно доповнювала регламентацію економічних домовленостей між ними. Радянсько-турецький договір надавав турецьким комерсантам право закуповувати в СРСР і безліцензійно вивозити товари 26 товарних груп 3 деякими обмеженнями та зауваженнями щодо цукру, нафтопродуктів та ікри. У травні 1928 р. Наркомторг СРСР тимчасово (до 30 вересня) дозволив туркам у вигляді поступки вивозити за ліцензіями низку інших товарів (виноградне вино, коньяк i коньячний спирт, музичні інструменти, проекційні апарати, фотопластинки, засоби дезінфекції, саліцилову кислоту, аптекарські товари, галенові препарати, алкалоїди, патентові засоби, хімікалії, хлористе вапно, іхтіол, фруктові екстракти, смоляну паклю, канати та шпагат, макарони, шоколад, гірчицю) (ДАОО, ф. Р-962, оп. 1, спр. 77, арк. 88).

Через Одеський порт у 1928 р. імпортували цитрусові, під час ввезення яких митники виявляли певні зловживання. Зокрема, у березні 1928 р. митники знаходили випадки, іноді завдяки моніторингу іноземної преси, коли замість заявлених турецьких ввозили італійські та сирійські лимони та помаранчі (ввезення турецьких було пільговим) (ДАОО, ф.Р-962, оп. 1, спр. 77, арк. 48). Схоже на те, що за сертифікатами як турецькі ввозилися й інші нетурецькі товари, що, на думку радянського митного керівництва, слід було кваліфікувати як контрабанду (ДАОО, ф. Р-962, оп. 1, спр. 77, арк. 63). Рекомендувалося у квітні 1928 р. орієнтувати фахівців-експертів при митницях на перевірку і виявлення нетурецьких товарів, які надходили до СРСР через Туреччину.

Значні шанси для радянської зовнішньої торгівлі надала Велика депресія, що з 1929 p. охопила провідні капіталістичні країни. Необхідність виживання спонукала держави 
Заходу забувати про політичні претензії до СРСР і посилювати 3 ним економічні відносини. Як СРСР використовував кризу для тиску на західних партнерів можна побачити на прикладі радянсько-італійських переговорів, які завершилися 2 серпня 1930 p. торгово-фінансовою угодою між двома державами (Москва-Рим, 2003, с. 236), що зумовило тісну економічну співпрацю двох тоталітарних режимів протягом 1930-х рр. У цілому за роки Великої депресії Італія потроїла свій імпорт до СРСР, що було взаємно вигідно для режимів Б. Муссоліні та Й. Сталіна (Москва-Рим, 2003, с. 295).

\section{Висновки.}

Аналіз середземноморської радянської зовнішньої торгівлі у 1920-х рр. дозволяє дійти таких висновків:

\section{- середземноморський}

напрям

радянської зовнішньої торгівлі періоду нової економічної політики слід визнати в цілому другорядним, адже в досліджуваному регіоні бачимо лише дві держави - Францію та Італію, які можна зарахувати до більшменш серйозних економік того часу. Хоча Середземномор'ям можна було дістатися й Британії та США, основним шляхом сполучення 3 останніми залишалася Балтика 3 Атлантикою. Тим не менш, вагу Середземноморського басейну для радянської держави підвищували його транзитні можливості та деякі логістичні нюанси;
- Середземномор'ямалодлярадянського режиму й значне геополітичне значення. Більшовики-комуністи завжди розглядали економіку виключно як засіб досягнення політичних цілей. Тому не дивно, наприклад, що економічні зв'язки з молодою Турецькою республікою пояснювалися необхідністю допомогти кемалістській революції. Італія ж, завдяки симпатіям до більшовиків 3 боку місцевих соціалістів, стала однією 3 перших західних країн, що виступили проти продовження економічної блокади «країни Рад». Середземноморський регіон включав значні колоніальні та підмандатні території, на яких під прикриттям торговельних операцій можна було пропагувати ідеї світової революції;

- на відміну від СРСР у цілому, для УСРР південний вектор зовнішньої торгівлі з об'єктивних причин відігравав провідну роль. Проте, якщо на початках радянського режиму Україна ще мала якусь економічну незалежність (можливість мати власні торговельні представництва за кордоном, самостійно здійснювати експортноімпортні операції тощо), то після створення СРСР і згортання непу така самостійність була повністю нівельована. 3 наступного десятиріччя українська сировинна і товарна продукція, істотно представлена саме в зоні Середземномор'я, визнавалася за кордоном як загально радянська чи навіть російська.

\section{БІБЛІОГРАФЛЧНІ ПОСИЛАННЯ}

Архірейський Д. В. Україна у радянсько-італійській торгівлі у 1920-х рр. Культура народов Причерноморья, 2008, 145, С. 52-55.

Архірейський Д. В. та Новотоцьких А. В. Українсько-турецькі торговельні відносини у 1920-х pp. Icmopiя торгівлі, податків та мита, 2013, 2, С. 140-150.

Архірейський Д. В. Україна у радянській зовнішній торгівлі доби нової економічної політики. Історія торгівлі, податків та мита, 2015, 1, С. 167-185; 2, С. 190-209.

Великий князь Александр Михайлович. Воспоминания. Мемуары. Минск: Харвест, 2004. 1990.

Верстюк В. Ф., Дзюба Е. Н. и Репринцев В. Ф. История Украинской ССР: Хронол. справ. Київ: Наукова думка,

Верт Н. Історія Радянської держави. 1900-1991: навч. посіб. Рівне: Вертекс, 2001.

Вєдєнєєв Д. В. та Будков Д. В. Юність української дипломатії. Становлення зовнішньополітичної служби Украӥнської держави. 1917-1923 роки. Київ: К.І.С., 2006.

Врангель П. Записки. Ноябрь 1916 г. - ноябрь 1920 г. Т. 2: Воспоминания, мемуари. Минск: Харвест, 2002.

Державний архів Одеської області (ДАОО).

Державний архів Російської Федерачиї (ДАРФ). Ф. Р-5446, оп. 5-а.

Державний архів Харківської області (ДАХО). Ф. Р-341, оп. 3.

Кульчицький С. Комунізм в Україні: перше десятиріччя (1919-1928). Київ: Основи, 1996. 
Майский И. М. Воспоминания советского дипломата. 1925-1945 г2. Москва: Наука, 1971.

Марков Л. Н. Очерки по истории таможенной службы. Иркутск: Изд-ние Иркут. ун-та, 1987.

Москва-Рим: Политика и дипломатия Кремля, 1920-1939: сб. документов. Москва: Наука, 2003.

Мунчаев Ш. М. и Устинов В. М. История Советского государства: учеб. Москва: Издательство НОРМА, 2002.

Нежинский Л. Н. В интересах народа или вопреки им? Советская международная политика в 1917-1933 годах. Москва: Наука, 2004.

Російський державний архів економіки (РДАЕ). Ф. 413, оп. 14.

Собрание узаконений и распоряжений правительства за 1917-1918 г2., 1942. № 33.

Соколофф, Ж., 2008. Бедная держава. История России с 1815 года до наших дней. Москва: Издат. дом ГУ ВШЭ.

Центральний держсавний архів вищих органів влади і управління України (ЦДАВО України). Ф. Р-2, оп. 1.

Центральний державний архів громадських об’єднань Украйни (ЦДАГО Украӥни). Ф. 1, оп. 20.

\section{REFERENCES}

Arkhireyskyi, D. V. (2008). Ukraina u radiansko-italiiskii torhivli u 1920-kh rr. [Ukraine in Soviet-Italian trade in the 1920s]. Kultura narodov Prychernomoria, 145, 52-55 [in Ukrainian].

Arkhireyskyi, D. V. \& Novototskykh, A. V. (2013.) Ukrainsko-turetski torhovelni vidnosyny u 1920-kh rr. [UkrainianTurkish trade relations in the 1920s]. Istoriia torhivli, podatkiv ta myta, 2, 140-150 [in Ukrainian].

Arkhireyskyi, D. V. (2015). Ukraina u radianskii zovnishnii torhivli doby novoi ekonomichnoi polityky [Ukraine in Soviet foreign trade of the period of the new economic policy]. Istoriia torhivli, podatkiv ta myta, 1, 167-185; 2, 190-209 [in Ukrainian].

Velikiy knyaz Aleksandr Mikhaylovich (2004). Vospominaniya. Memuary [Memories. Memoirs]. Minsk: Kharvest [in Russian].

Verstyuk, V. F., Dzyuba, E. N. \& Reprintsev, V. F. (1990). Istoriya Ukrainskoy SSR: Khronol. sprav. [History of the Ukrainian SSR: Chronological reference book]. Kyiv: Naukova dumka [in Russian].

Vert, N. (2001). Istoriia Radianskoi derzhavy. 1900-1991: navch. posib. [History of the Soviet state. 1900-1991: textbook]. Rivne: Verteks [in Ukrainian].

Viedienieiev, D. V. \& Budkov, D. V. (2006). Yunist ukrainskoi dyplomatii. Stanovlennia zovnishnopolitychnoi sluzhby Ukrainskoi derzhavy 1917-1923 roky [Youth of Ukrainian diplomacy. Formation of the foreign policy service of the Ukrainian state. 1917-1923]. Kyiv: K.I.S [in Ukrainian].

Vrangel, P. (2002). Zapiski. Noyabr 1916 g. - noyabr 1920 g. [Notes. November 1916 - November 1920]. Vol. 2: Vospominaniya. Memuari. Minsk: Kharvest [in Russian].

Derzhavnyi arkhiv Odeskoi oblasti (DAOO) [State Archive of Odesa Region] [in Ukrainian].

Derzhavnyi arkhiv Rosiiskoi Federatsii (DARF) [State Archive of the Russian Federation]. F. R-5446, op. 5-a [in Ukrainian].

Derzhavnyi arkhiv Kharkivskoi oblasti (DAKhO) [State Archive of Kharkiv Region]. F. R-341, op. 3 [in Ukrainian].

Kulchytskyi, S. (1996). Komunizm v Ukraini: pershe desiatyrichchia (1919-1928) [Communism in Ukraine: the first decade (1919-1928)]. Kyiv: Osnovy [in Ukrainian].

Mayskiy, I. M. (1971). Vospominaniya sovetskogo diplomata. 1925-1945 gg. [Memoirs of a Soviet diplomat. 19251945]. Moskva: Nauka [in Russian].

Markov, L. N. (1987). Ocherki po istorii tamozhennoy sluzhby [Essays on the history of the customs service]. Irkutsk: Izd-niye Irkut. un-ta [in Russian].

Moskva-Rim: Politika i diplomatiya Kremlya. 1920-1939: sb. dokumentov [Moscow - Rome: Politics and diplomacy of the Kremlin, 1920-1939: collection of documents]. (2003). Moskva: Nauka [in Russian].

Munchayev, Sh. M. \& Ustinov, V. M. (2002). Istoriya Sovetskogo gosudarstva: ucheb. [History of the Soviet state: textbook]. Moskva: Izdatelstvo NORMA [in Russian].

Nezhinskiy, L. N. (2004). V interesakh naroda ili vopreki im? Sovetskaya mezhdunarodnaya politika v 1917-1933 godakh [In the interests of the people or in spite of them? Soviet foreign policy in 1917-1933]. Moskva: Nauka [in Russian]. Rosiiskyi derzhavnyi arkhiv ekonomiky (RDAE) [Russian State Archives of Economics]. F. 413, op. 14 [in Ukrainian]. Sobraniye uzakoneniy i rasporyazheniy pravitelstva za 1917-1918 gg. [Collection of legalizations and orders of the government for 1917-1918] (1942). 33 [in Russian].

Sokoloff, Zh. (2008). Bednaya derzhava. Istoriya Rossii s 1815 goda do nashikh dney [Unhappy power. History of Russia from 1815 to the present day]. Moskva: Izdat. dom GU VShE [in Russian].

Tsentralnyi derzhavnyi arkhiv vyshchykh orhaniv vlady i upravlinnia Ukrainy (TsDAVO Ukrainy) [Central State Archive of the highest authorities and administration of Ukraine]. F. R-2, op. 1 [in Ukrainian].

Tsentralnyi derzhavnyi arkhiv hromadskykh obiednan Ukrainy (TsDAHO Ukrainy) [Central State Archive of Public Associations of Ukraine]. F. 1, op. 20 [in Ukrainian].

Arkhireyskyi Dmytro

Dr. Sc., Assoc. Prof., https://orcid.org/0000-0003-0105-3510, siverin47@ukr.net 